\title{
Challenges With The FinAnCial Reporting OF Biological Assets by Public Entities in South Africa
}

\author{
Deon Scott, Christa Wingard and Marilene van Biljon \\ Financial Accounting, University of South Africa \\ Accepted: September 2015
}

\begin{abstract}
Fair value accounting of biological assets in the public sector was introduced with the adoption of the publicsector-specific accounting standard: Generally Recognised Accounting Practice (GRAP) 101. The public sector currently reports on various bases of accounting. Public entities and municipalities report in terms of accrual accounting, and government departments report on the modified cash basis. The lack of a uniform basis of accounting impedes the comparability of financial information. The implementation of GRAP 101 in the public sector is important in facilitating comparability of financial information regarding biological assets. This paper is based on a content analysis of the annual reports of 10 relevant public entities in South Africa and specifically details the challenges that public entities encounter with the application of GRAP 101. These challenges, and how they were addressed by a public entity that adopted and applied GRAP 101, namely the Accelerated and Shared Growth Initiative South Africa - Eastern Cape (AsgiSA-EC), are documented in this research.
\end{abstract}

Key words: fair value, biological assets, public entity/sector, GRAP 101, accounting challenges, modified cash basis, accrual basis

JEL: M48

\section{$1 \quad$ Introduction}

The accounting of biological assets, other than livestock, was introduced to the accounting fraternity with the development of the International Accounting Standard on Agriculture, IAS 41 (IASB, 2011:par.B1-B7). The adopted IAS 41 replaced the previously applied AC 205 standard, which only addressed the recognition of livestock as a biological asset (Shuttleworth, 2002). A government-specific accounting standard on the reporting of biological assets, Generally Recognised Accounting Practice (GRAP) 101, Agriculture (ASB, 2006), was derived from the principles of IAS 41. GRAP 101 has been replaced by GRAP 27, Agriculture, but the principles in this standard are still similar to IAS 41 and GRAP 101. An evaluation of the financial statements of the 10 public entities reporting on biological assets up to 2011 in South Africa confirmed that an implementation norm was not established to recognise, measure and value biological assets, and the requirements of GRAP 101 were not unanimously applied. A uniform application of GRAP 101 will enhance comparability and, consequently, the value of financial information on biological assets in the public and private sectors.

This paper details the challenges experienced by public entities in general, but, specifically, by the Accelerated and Shared Growth Initiative South Africa - Eastern Cape (AsgiSA-EC), in the fair value accounting and reporting of biological assets. AsgiSA-EC is the only public entity in the sample which adopted GRAP 101 for reporting on biological assets and was subsequently directly confronted with a number of challenges. Some, or all of these challenges, were evident from the decision of the other entities in the sample not to adopt GRAP 101 without an implementable guideline for reporting the fair value of biological assets.

The literature review, research methodology, and research findings, including the seven challenges experienced with the fair valuing of biological assets, are discussed before reaching the conclusions and making recommendations to assist the public sector with these challenges. 


\section{Literature review}

There is limited literature relating to the fair valuing of biological assets. Moreover, the challenges concerned and the non-compliance with GRAP 101 have not been addressed in any research to date. The literature has focused mainly on a principles-based approach.

Effective accounting for, and reporting on, the fair value of biological assets has been a challenge since its introduction in 2006 in South Africa (ASB, 2006). Even in the private sector, which is regarded as the frontrunner when it comes to compliance with accounting standards, challenges regarding the implementation of their equivalent accounting standard, IAS 41, are evident (Gonçalves \& Lopes, 2014; Argilés, Blandón \& Monllau, 2013; Elad \& Herbohn, 2011; Aryanto, 2011; Rozentãle \& Ore, 2013). Elad and Herbohn's (2011:94) research conducted on the fair valuing of biological assets in the private sector revealed that, out of a total of 103 companies studied from three different countries, a mere 11 per cent of the Australian companies, 19 per cent of the companies in the United Kingdom, and 25 per cent of the companies in France applied the principles of fair value accounting. A study by Baigrie (2014), analysing the financial reporting compliance of South African public agricultural companies, found that different valuation models were used for the valuation of biological assets. Fifty per cent of the companies used future cash flows, 38 per cent used fair value based on adjusted market prices, 6 per cent used cost less accumulated depreciation, and 6 per cent did not indicate any valuation model or method (Baigrie, 2014:75). The above-mentioned information confirms that a uniform application of IAS 41 does not exist, even in the private sector. The study by Elad and Herbohn (2011:105) further highlighted the inconsistency in auditors' expression of an opinion on the non-implementation of the requirements of the standard as a result of the non-existence of an implementation norm.

In a study conducted in Kenya, Maina and Wingard (2013) found that the most significant challenge is the lack of an active and transparent market when determining fair value of biological assets for small and medium-sized entities (SMEs). Sitko and Jayne (2012) point out that, with the exception of South Africa, commodity exchanges in Africa have not yet achieved the necessary market size to function efficiently. They state that the governments in the region, for example Zambia, regularly intervene in cereal markets to ensure adequate food supplies at tolerable prices (Sitko \& Jayne, 2012:281), but that government intervention is not necessarily incompatible with commodity exchange development as long as it does not introduce major unpredictability into the market.

In South Africa, the Public Finance Management Act 1 of 1999 (as amended) (South Africa, 1999) requires of public entities to comply with GRAP. In practice, it is found that a number of public entities have not implemented GRAP and are still using the modified cash basis of accounting (ASB, 2014).

Reporting on the modified cash basis of accounting does not recognise accruals in the statement of financial position but merely discloses available information in the notes to the financial statements. Transactions incurred in respect of debt, for example normal purchases and sales where the creditors and debtors will pay or be paid later, are not recorded in the financial records when the transactions occur. Recording is done only when the actual cash is received or paid on the credit sales and/or purchases (IPSASB, 2011).

The public-sector entities that report in terms of the modified cash basis of accounting will only recognise a biological asset on payment. Biological assets of a value not exceeding R5 000 will not be capitalised and disclosed as an asset in the statement of financial position (South Africa, 2009), as National Treasury issued a "Circular" excluding purchases of a value lower than R5 000 from the asset listing, and these purchases are directly expensed (South Africa, 2009). Biological assets exceeding R5 000 are recorded in the financial records as an asset - with no consideration of the fair valuing principles - in terms of the modified cash basis of accounting when the purchase is paid for. Biological assets can thus either be disclosed as expenses (below R5 000) or an asset (above R5 000) held at cost in the financial records. 
Paragraph 2 of GRAP 101 (ASB, 2006) requires public entities to apply the principles of accrual accounting. Transactions are recorded as and when they occur and include both cash and credit transactions. Biological assets accounted for in terms of the accrual basis of accounting are recognised when purchased or on delivery, whichever event occurs first. The accrual basis of accounting will reflect the biological asset as a non-current asset in the financial records when these assets are held for a period longer than 12 months. The principles of GRAP 101 will be applied to measure and disclose the biological assets in the financial statements at the reporting date. As the users of financial statements need to make informed decisions on the information at hand, accrual financial statements are considered to be more reliable than those presented on the modified cash basis (IPSASB, 2011).

\section{Research method}

Public-sector entities that need to account for biological assets were identified by evaluating the core business operations per entity listed in the Public Finance Management Act 1 of 1999, as amended by Act 29 of 1999 (PFMA) (South Africa, 1999).

Published secondary data, represented by the 2011 financial statements of public entities in South Africa, were used for the analysis. The financial records of AsgiSA-EC are open for public review, as they are published on the entity's website. However, permission was obtained from the management of AsgiSA-EC, which was the only entity that applied GRAP 101, and this resulted in a more detailed analysis.

Of a total of 297 listed public entities, 10 public entities were identified that hold and account for biological assets in South Africa (South Africa, 2011c). The financial statements of these entities were analysed by means of content analysis to determine the accounting basis applied in order to account for biological assets. Of these 10 entities which account for biological assets, only one, AsgiSA-EC, adopted the fair value accounting principles in terms of the prescribed standard of GRAP 101. The formal audit reports and schedules of the Auditor-General were used as control measures for the assessment of the implementation of, and compliance with GRAP 101, by the sampled public entities.

Content analysis was used to identify the challenges experienced by the sampled public entities in adopting, or preventing the adoption and implementation, of the prescribed fair value accounting principles.

\section{Research findings}

The detailed review of the financial statements of the listed public entities confirmed that 10 entities were required to report on biological assets. Of these, only AsgiSA-EC fair-valued biological assets and reported in terms of the requirements of GRAP 101 (AsgiSA-EC, 2011). Limited application of GRAP 101 was identified at the Eastern Cape Parks Board, which only accounts for biological assets earmarked for sale within 12 months of the reporting date, measured at the cost of the sold hunting packages (ECPB, 2009). Fair value accounting of biological assets was not applied by the other eight entities. A review of the accounting of biological assets in the public sector was published in July 2014 by the Accounting Standards Board (ASB, 2014). In this discussion paper, the Accounting Standards Board (ASB) aims to simplify the accounting treatment of living and non-living resources in the public sector, as it details the current inconsistent treatment on the part of the national departments to which all public entities report (ASB, 2014).

The biological assets held by the non-compliant eight entities were accounted for as (i) an expense; (ii) at point of sale only; and (iii) on the modified cash basis of accounting. The Eastern Cape Rural Finance Corporation Limited (ECRFC) disclosed the biological assets purchased at the transaction date as an expense. Subsequent valuations were not performed, as the biological assets were accounted for as part of an administered fund (ECRFC, 2011). The South African National Parks and the Limpopo Tourism and Parks Board only account for biological assets when they are sold. The revenue derived from the sale of the biological assets is recorded, with no consideration 
given to the fair valuing or accounting for any asset (SANParks, 2011; South Africa, 2010b). The remaining five entities account for biological assets on the modified cash basis of accounting and thus only record actual purchases of biological assets (South Africa, 2010a; South Africa, 2011a; South Africa, 2011b; Casidra, 2010).

The variation in application of GRAP 101, and the subsequent variation in the valuation and reporting of biological assets by public entities, can be attributed to challenges in the interpretation and implementation of the standard.

\section{Challenges experienced with the fair valuing of biological assets}

The challenges identified in the fair valuing of biological assets in the public sector were identified and described by analysing the accounting principles as presented by GRAP 101 and comparing them with the practical application by the sampled public entities. The identified challenges are as follows:

\subsection{Challenge 1: The absence of an active market}

In the absence of markets, management needs to rely on estimates and judgements to determine the fair value of biological assets. GRAP 101 (ASB, 2006:par 22) provides guidance for management in calculating a fair value when active markets do not exist for the biological assets held (AsgiSA-EC, 2011; Maina, 2010:60).

The absence of active markets requires management to assess the available markets and market information and to perform a review of the economic trends and conditions from the previous reporting date to the current reporting date. Should the economy appear to have been stable during the financial period, the most recent market prices may be used in the calculation of the fair values of biological assets (ASB, 2006:par 22; Maina 2010:60; Munjanja, 2008:23).

Management needs to assess similar market information in instances where the biological asset is so scarce or rare that an active market has not existed during the reporting period, or where the economic trends are significant and historic information is considered to be unreliable (ASB, 2006:par 22). Information on the similarities between the biological assets identified, the valuation methods applied, and the calculations need to be documented. Section 55(1) of the PFMA requires a portfolio of evidence to be maintained in respect of all calculations, data, assumptions, market information, techniques and estimates applied by management to support the information disclosed in the financial records (South Africa, 1999).

The absence of active markets and market information may result in management arriving at judgements and estimates from sector benchmarks at the reporting date. The sector information applied in the valuation should be narrated and supported by substantiating evidence of the variables and prices used in the valuation process (ASB, 2006:par 22; Maina, 2010:60).

The fair valuing of biological assets in the absence of active markets may be a costly exercise in the public sector. To validate the judgements, assumptions and estimates applied, an independent review by the internal auditors will provide guidance and recommendations in support of the overall valuation process. The internal audit report will support management during the external audit process where public accountability takes priority. Van Schweitzer (2009) regards internal audit reviews as the "conscience of the organisation", as such reviews provide stakeholders with the assurance of responsible expenditure of public funds.

\subsection{Challenge 2: A lack of available valuation techniques}

Public entities in South Africa do not apply a uniform approach to account for biological assets, as guidance has not been given on how management should value these biological assets. The physical valuation process and the underlying factors that management should consider when valuing biological assets are not detailed in manuals or policy documents. In addition, when crops mature on a date different from the reporting, and thus valuation, date, management should consider factors such as the growth/maturity stages and the discounting of market prices. 
AsgiSA-EC has experienced a challenge valuing biological assets at financial year-end when the biological assets will only mature later. The planting of crops, specifically soya beans, dry beans and maize, is done from October to December. Harvesting occurs once the biological transformation process has been completed and the expected moisture levels have been reached, usually around June. The financial year-end is on 31 March (the middle of the agricultural year) when the plants are in a growing stage and thus not in a condition to be harvested (AsgiSA-EC, 2011:1). Management needs to consider the agricultural time frames and growth factors in the calculations supporting the fair value determination.

The application of different accounting principles by similar entities might be as a result of the lack of guidance from National Treasury. Treasury provides entities with interpretation guideline publications and prescribes specific requirements regarding the financial statements of the public sector. However, guidance and industry norms are not channelled to public entities to guide the valuation process and available techniques. The estimates and assumptions applied are to be developed and reviewed by internal auditors and possibly experts, and detailed in a tailor-made policy. The assumptions and techniques applied are further not disseminated among similar entities so as to set an industry norm or standard.

The lack of guidance may result in unreliable fair values when experts and internal auditors do not assist the public entity to determine a basis for the calculations. However, this lack of guidance does not exempt management from applying the requirements of GRAP 101. Ignorance of the GRAP 101 requirements may result in a qualified audit opinion from the office of the AuditorGeneral. The board, and, specifically, the chief executive officer and chief financial officer of the entity may be held personally accountable for the non-compliance by the Standing Committee on Public Accounts (SCOPA) (Heathcote \& Human, 2008:24).

\subsection{Challenge 3: A lack of understanding of the application of the GRAP requirements}

To comply with the definition of a biological asset, GRAP 101 requires "service potential" to be considered in conjunction with the "future economic benefits" which may be anticipated by a public entity. The service potential of a public entity might refer to the ability of the entity to sign contractual agreements to sustain operations. It may also refer to the relationships between stakeholders and the ability of the entity to perform in order to deliver on predetermined objectives that are set by government (ASB, 2006:par 13).

"Service potential" relating to public entities is seldom measured in terms of a pure economic value. A major challenge for a public entity exists if it does not own any land. In the case of AsgiSA-EC, the land used in the agricultural production and biological transformation processes belongs to the community. Community contracts are signed between the relevant chief of the community and the individual landowners of the tracts of land. AsgiSA-EC, in turn, signs a contract with the chief and the community representative for the right to plant on community land. For AsgiSA-EC, service potential does not only relate to the biological transformation, but also the strengthening of the relationships with the community with a view to the future use of the land (AsgiSA-EC, 2011:107).

Public entities should define their service-potential strategies to determine how future economic benefits will be derived from the controlled biological assets. Public entities should not disregard the recognition and accounting of biological assets merely as a result of service-potential abilities not being defined. The "service-potential" criteria for AsgiSA-EC will be measured in terms of whether the communities are willing to extend their land-usage contracts. In the event of communities cancelling their contracts with AsgiSA-EC, there will be no service potential for the public entity and the definition of a biological asset will need to be reassessed by management.

\subsection{Challenge 4: High costs related to the fair value accounting of biological assets}

The costs associated with determining the fair value of biological assets are excessive, especially when an expert needs to perform the valuation. There are specific requirements that need to be met 
when an expert is consulted or contracted to do the valuation, for example professional membership of a recognised professional body, such as a valuer's institution, is required by the Office of the Auditor-General. Management needs to perform an assessment of the qualifications and experience of the valuer before contracting the individual. This review will ensure that the best valuation methods are applied in the accounting of biological assets (IRBA, 2011).

Management will remain responsible for the valuation process despite the use of experts. Management oversight might result in additional costs being incurred as a result of extensive feedback that the expert may be required to provide. The responsibilities of the contracted expert during the valuation process should be stipulated and agreed upon by the parties prior to the valuation. Management needs to implement measures to ensure that the work performed by the expert is objective and unbiased (IRBA, 2011). Management remains accountable for the information compiled and presented by the expert. It should assess the work performed, as well as approve and accept the valuation process and results as prepared by the expert. The underlying valuation documentation and calculations will be subject to statutory audit by the Office of the Auditor-General, and management must, therefore, be able to provide the auditors with appropriate audit evidence that supports the valuation process.

In the public sector, where discounting is not a standard practice and calculations of this nature are not performed regularly, the review of the calculations performed may be subject to an external review. An external review will result in additional costs for the public entity, which costs may not have been budgeted for (Van Schweitzer, 2009:19). In terms of GRAP 101, the discounted cash flow model needs to be applied to determine the fair value of the biological assets, with special consideration of the condition and location of the biological assets at the financial year-end (ASB, 2006:par 25).

Costs associated with the auditing of biological asset valuations might be substantial for the public sector. In terms of paragraph 27.2 of the National Treasury Regulations and section 51(1)(a)(ii) of the PFMA, all public entities are required to have an internal audit function, either in-house or as an external audit firm appointed for the entity (South Africa, 1999; South Africa, 2005). Effective and efficient controls should be derived by management from the internal audit processes when recommendations for improvements by the auditors are implemented (ISSAI, 2011a; ISSAI, 2011b). The stated legislation requires the internal audit function to perform a review of the controls in respect of the information systems, the financial and operational information, and the effectiveness of the operations, the safeguarding of the entity's assets, and compliance with the prescribed laws and regulations applicable to the entity (South Africa, 2005; South Africa, 1999). The safeguarding of the biological assets held by the public entity will form part of the scope of the internal audit. Tests of control will be developed and executed by the internal auditors in order to assess the risks identified at the entity, the control requirements in terms of the approved policies, and the procedures established (South Africa, 2005; South Africa, 1999).

\subsection{Challenge 5: A lack of guidance and/or templates in respect of policies or procedures that should be adopted by the entity}

Section 50(1) of the PFMA requires an accounting authority (the board) of a public entity to safeguard all assets and records of the entity and to manage the finances in the best interest of the entity. Furthermore, section 51 of the PFMA requires an efficient and effective financial and control system to be established and implemented (section 57) by each employee of the public entity (South Africa, 1999; South Africa, 2005). Compliance with the PFMA will be addressed as the entity develops, approves and implements policies detailing the legal requirements and the desired procedures. Currently, each public entity assesses the available guide and develops policies and procedures for the financial components applicable to the entity (South Africa, 1999; South Africa, 2005). 
Technical Memorandum 16 of 2009, issued by the office of the Auditor-General on 3 July 2009, provided guidance for departments and public entities on the treatment of biological assets in the financial records (Office of the Auditor-General, 2009). The memorandum highlighted that the intended use of the biological asset should be considered by management to determine the standard of GRAP to be applied in the accounting treatment. The accounting treatment guidance can assist management to compile an entity-specific internal control policy and procedure manual. The policy and related procedure manual on biological assets should detail the legislative requirements and those of GRAP 101. The objective of the procedure manual is to provide guidance on the identification, recognition, valuation, safeguarding, reporting and managing of biological assets (South Africa, 1999; South Africa, 2005).

The entity-specific policy needs to address the unique circumstances of the entity and the management of its biological assets. Management will need to assess the nature of the biological assets held and the intended use of these assets. A review of the mandate of the public entity and the operational activities may be required to establish the various kinds of biological assets applicable to the entity. Detailed guidance on the biological assets needs to be included in the manuals in order to provide clarity, for the users of financial information, on the distinction between biological assets (Office of the Auditor-General, 2009). The biological assets held by the entity are thus evaluated by management to determine the required internal controls. Detailed guidance and assistance on the application of the standards and the related controls are not available to management to ensure a uniform application of controls and accounting principles.

The lack of an industry norm was highlighted when the Technical Memorandum detailed that biological assets actively managed will be reported in terms of GRAP 101, while biological assets held for recreational purposes and those held for a period longer than 12 months, in the production or supply of goods and services, will be treated as Property, Plant and Equipment (GRAP 17) (ASB, 2004; Office of the Auditor-General, 2009). GRAP 12, Inventories, will be applied to biological assets that are used in the production of goods or further biological assets. Biological assets held by a public entity for investment purposes will be treated and disclosed in terms of GRAP 16, Investment Property.

\subsection{Challenge 6: Absence of templates or application process in respect of an accounting policy in terms of GRAP 101}

Section 55(1) of the PFMA and paragraph 28.1.6 of the Treasury Regulations require an accounting authority (the board of the public entity) to prepare financial statements for each financial year in terms of the standards approved by the ASB. The financial statements of an entity should include accounting policies detailing the principles and methods applied in the recognition, measurement, valuation and disclosure of biological assets. The accounting policies should be based on the requirements of GRAP 101, as the ASB has prescribed this standard as the basis of accounting for public entities with departments reporting in terms of the modified cash basis (South Africa, 2005; South Africa, 1999; ASB, 2006:par 02). A lack of a uniform application of the standards of GRAP at public-entity level resulted in only one entity, AsgiSA-EC, applying the required principles. The application of the multiple bases of accounting impaired the objective of enabling users of financial information to compare financial results of the public sector with other industries.

The accounting policy and the organisational policy of the entity should be aligned with each other and to GRAP 101. These policies should be reviewed on an annual basis by management and the board to ensure that legislative requirements and development are incorporated and that the accounting treatment is still relevant and applicable (South Africa, 1999:section 51).

\subsection{Challenge 7: Restricted budgets, and budget management reporting with regard to fair value accounting}

The fair value accounting of biological assets at each reporting date, being year-end, may result in a fair value adjustment (ASB, 2006:par 15; ASB, 2006:par 30; ASB, 2006:par 17). A fair value 
adjustment will occur when the fair value of the biological asset exceeds the value at which the biological assets have been recorded in the financial system. A positive fair value adjustment will result in a credit on the financial system; thus an increase in the revenue reported on by public entities. In turn, a negative fair value adjustment will result in a debit on the financial system; thus an expense. The fair value adjustment in respect of the biological assets will impact on the net surplus or deficit of the public entity.

When fair value adjustments result in a net deficit, the financial information will not comply with the Treasury Regulations. Budget management of a public entity is regulated by the PFMA and the Treasury Regulations. In no circumstances may a public entity budget for a deficit, as regulated by section 53(3) of the PFMA. The entity budget will detail the projected cash flows and anticipated revenues and expenses. There will not be any consideration of the non-cash-based fair value adjustments with respect to the biological assets included in the entity budget. The actual financial results of the entity will include these fair value adjustments and can result in a reported net deficit for the entity. The onus will be on management to provide the Standing Committee with management plans and documentation to substantiate the accounting deficit. Management will be able to misrepresent the financial results of the entity when a fair value profit "hides" the actual deficit incurred for the year.

\section{$6 \quad$ Impact of fair value reporting on the public sector}

The adoption of IAS 41 and the related fair value disclosure of biological assets by companies in various countries promote comparability of the performance and position of the biological assets of the various companies. Analytical reviews can be performed on the information disclosed by the various companies so as to study market trends and sector performance, as well as for the enhancement of management processes in the management accounting and budgetary forecasts.

Likewise, the adoption of GRAP 101 by government entities will ensure that the financial information disclosed by private companies can be compared with overall government performance. The uniform standard will assist management to assess the performance of the entities in order to enhance, strengthen and broaden initiatives taken by government to have effective and efficient systems monitoring and reporting on biological assets. The implementation of enhanced systems will focus management's efforts and attention on the development of techniques and methods centred on the core business of food production and the related fight against hunger and poverty.

As GRAP 101 is based on the requirements of IAS 41, similar challenges in the fair value accounting of biological assets could have been experienced in the private sector in fair-valuing these assets. Fair value accounting in public entities should not be limited by the challenges that have been identified, for the following reasons:

1) The public entities have converted from South African Generally Accepted Accounting Practice (SA GAAP) to GRAP. The principles of GAAP are based on accrual accounting and all transactions were included in the accounting records before the conversion to GRAP was initiated. Government departments, however, face a crisis with the conversion to GRAP, as non-cash transactions are not recorded in the financial records of the departments.

2) Government developed a phase-in approach in the implementation of the requirements of GRAP. The phase-in approach allowed ample time for public entities to study the reporting requirements and to implement policies and procedures to sufficiently address the reporting requirements. The lessons learnt should be analysed and implemented in the conversion to GRAP by the departments.

3) The methods, assumptions and disclosure techniques applied by private companies with regard to the fair-valuing of biological assets can be referred to for guidance, as the requirements of GRAP 101 are similar to those of IAS 41.

4) The South African public sector accounting revolution commenced in 2003 with the adoption of standards of GAAP and the subsequent GRAP standards. Disclosing transparent 
information in a government sphere enhances resource allocations and better management of available funding (Van Schaik \& Sanderson, 2008).

\section{Conclusions}

The absence of implementation guidelines for the accounting and reporting of biological assets in terms of GRAP 101 is one of the reasons why public entities do not comply with the required accounting standard. This paper detailed the challenges experienced in the public sector in the fair value accounting of biological assets. The public sector in South Africa applies different bases of accounting. Government departments are reporting on the modified cash basis, while public entities and municipalities report in terms of the accrual basis of accounting. The principles of the accrual basis of accounting and the related accounting for biological assets in terms of GRAP 101 are not implemented consistently in the public sector. This may influence decision making, as it will be based on reported non-comparable values of biological assets.

The objective of reporting in terms of GRAP by all spheres of government is to obtain comparable financial information in both the public and private sectors. The process necessary to comply with the above objective is not expected to be without its challenges. This study aimed to analyse the specific challenges experienced by public entities with the implementation of fair value accounting principles in respect of biological assets, as well as reporting them in terms of GRAP 101. The challenges addressed may provide useful guidance for non-compliant public entities in the implementation of GRAP101.

\section{Recommendations}

This research identified some specific GRAP 101 implementation challenges for public entities. To enhance the implementation and quality of fair value reporting of biological assets by public entities, it is recommended that National Treasury, which is the custodian of public-sector accounting standards:

5) assess the challenges as identified and addressed in this research;

6) develop detailed guidelines on the interpretation of the standard;

7) draft an accounting-policy template that complies with the requirements of GRAP 101;

8) develop internal control guidelines to manage, safeguard and report on biological assets; and

9) make available market information to assist in the valuation of biological assets.

\section{References}

ACCELERATED AND SHARED GROWTH INITIATIVE SOUTH AFRICA - EASTERN CAPE (AsgiSAEC). 2011. Annual financial statements. Available at: http://www.asgisa-ec.co.za/_[accessed August 2011]. ACCOUNTING STANDARDS BOARD (ASB). 2004. Generally Recognised Accounting Practice (GRAP). GRAP 17 Property, plant and equipment. Available at: http:/www.asb.co.za/component/content/article/ index.php?option $=$ com_content $\&$ view $=$ article $\&$ id $=54$ [accessed January 2011].

ACCOUNTING STANDARDS BOARD (ASB). 2006. Generally Recognised Accounting Practice (GRAP). GRAP 101 Agriculture. Available at: http://www.asb.co.za/component/content/article/index.php?option= com_content\&view $=$ article\&id $=62$ [accessed September 2010].

ACCOUNTING STANDARDS BOARD (ASB). 2014. Discussion paper 10: Accounting for living and nonliving resources. South Africa. Available at: http://www.asb.co.za/ [accessed January 2015].

ARGILÉS, J.M., BLANDÓN, J.G. \& MONLLAU, T. 2013. Fair value and historic cost accounting of biological assets. Spain: Department of Accounting, University of Barcelona. Available at: http://www.scribd.com/doc/124716943/IAS-41-Fair-Value-and-Historic-Cost-on-Biological-Assets [accessed March 2014].

ARYANTO, Y.H. 2011. Theoretical failure of IAS 41. SSRN. Available at: http://ssrn.com/abstract=1808413 or http://dx.doi.org/10.2139/ssrn.1808413. 
BAIGRIE, I. 2014. An analysis of the financial reporting compliance of South Africa public agricultural companies. MCom thesis. University of Johannesburg [unpublished]. Available at: https://ujdigispace. uj.ac.za/bitstream/handle/10210/14020/INGRID\%20BAIGRIE.pdf?sequence=1\&isAllowed=y [accessed August 2015].

CASIDRA. 2010. Report to Economic Development and Tourism Portfolio Committee. Available at: http://www.google.co.za/url?sa=t\&rct=j\&q=casidra\%2B(Pty)\%2Bltd\%2Bfinancial\%2Bstatements\&source= web\&cd $=2 \&$ ved $=0 \mathrm{CCcQFjAB} \& u r l=\mathrm{https} \% 3 \mathrm{~A} \% 2 \mathrm{~F} \% 2 \mathrm{Fwww}$. capetown.gov.za $\% 2 \mathrm{FGetDocument}$. aspx $\% 3 \mathrm{FU}$ niqueId\%3D38d0ba57-7e67-4802-8a5d-9e6d54f4d9ce\&ei=zWiETpG3Geau0QXD_tjrDw\&usg= AFQjCNE6xSHvz53GLlj-iHv-G38Xp160fw\&sig2=7jjLwxTlC3ezAfPZnMsmZg [accessed 2011-09-23]. EASTERN CAPE PARKS BOARD (ECPB). 2009. Annual report. Annual financial statements. Available at: http://www.ecparks.co.za/about-ecparks/reports.html [accessed 2010-08-07].

EASTERN CAPE RURAL FINANCE CORPORATION (ECRFC). 2011. Annual report for the financial year ended 31 March 2011. Annual report that details the operational results and the annual financial statements for the year ended 31 March 2011. Unpublished.

ELAD, C. \& HERBOHN, K. 2011. Implementing fair value accounting in the agricultural sector. Scotland: Institute of Chartered Accountants of Scotland. Available at: https://icas.org.uk/res/elad_report_feb_2011.pdf [accessed July 2012].

GONÇALVES, R. \& LOPES, P. 2014. Accounting in agriculture: Disclosure practices of listed firms. FEP working papers. University of Porto: School of Economics and Management. Available at: http://wps.fep.up.pt/wps/wp530.pdf [accessed July 2014].

HEATHCOTE, K. \& HUMAN, E. 2008. Framework fact file. Accountancy SA, June:24-27.

INDEPENDENT REGULATORY BOARD FOR AUDITORS (IRBA). 2011. International Auditing Standards, 620. Available at: http://www.irba.co.za/index.php/auditing-standards-functions55/517?task=view [accessed September 2011].

INTERNATIONAL ACCOUNTING STANDARDS BOARD (IASB). 2011. International Accounting Standards (IAS). IAS 41Agriculture. United Kingdom: International Accounting Standards Committee Foundation. Available at: http://www.iasplus.com/en/standards/standards/standard40 [accessed August 2011] INTERNATIONAL PUBLIC SECTOR ACCOUNTING STANDARDS BOARD (IPSASB). 2011. Transition to the accrual basis of accounting: Guidance for public sector entities. New York: International Federation of Accountants. Available at: http://www.ifac.org/publications-resources/study-14-transitionaccrual-basis-accounting-guidance-governments-and-governm [accessed July 2011].

INTERNATIONAL STANDARDS OF SUPREME AUDIT INSTITUTIONS (ISSAI). 2011a. INTOSAI GOV 9100 Guidelines for internal control standards for the public sector. Denmark: International Organisation of Supreme Audit Institutions. Available at: http://www.issai.org./media(574,1033)/ INTOSAI_GOV_9100_E.pdf [accessed July 2011].

INTERNATIONAL STANDARDS OF SUPREME AUDIT INSTITUTIONS (ISSAI). 2011b. INTOSAI GOV 9110 Guidelines for reporting on the effectiveness of internal controls: SAI experiences in implementing and evaluating internal controls. Denmark: International Organisation of Supreme Audit Institutions. Available at: http://www.issai.org./media(575,1033)/INTOSAI_GOV_9110_E.pdf [accessed July 2011].

MAINA, P.N. 2010. Fair value reporting challenges facing small and medium-sized entities in the agricultural sector in Kenya. Unpublished MCom (Accounting) dissertation. University of South Africa. Available at: http://uir.unisa.ac.za/handle/10500/4093 [accessed August 2011].

MAINA, P.N. \& WINGARD, H.C. 2013. Small and medium-sized entities in the agricultural sector: Fair value reporting challenges. Agrekon, 52(2):52-74.

MUNJANJA, I. 2008. Obstacles to determining the fair values of financial instruments in Mozambique. Unpublished MCom dissertation. University of South Africa. Available at: http://uir.unisa.ac.za/ handle/10500/1273 [accessed August 2011].

OFFICE OF THE AUDITOR-GENERAL. 2009. Technical Memorandum 16 of 2009. Internal guide to auditors on the interpretation of accounting standards and the related disclosure requirements. Unpublished. ROZENTÃLE, S. \& ORE, M. 2013. Evaluation of biological assets: Problems and solutions. Journal of Modern Accounting and Auditing, 9(1):57-67. 
SHUTTLEWORTH, B. 2002. Fair value accounting for agriculture. Accountancy SA. Available at: http://www.accountancysa.org.za/archives/2002/2002nov/features/AC137.htm. [accessed September 2010]. SITKO, N.J. \& JAYNE, T.S. 2012. Why are African commodity exchanges languishing? A case study of the Zambian Agricultural Commodity Exchange. Food Policy, 37:275-282.

SOUTH AFRICA. 1999. The Public Finance Management Act No. 1 of 1999 as amended by Act No. 29 of 1999 (PFMA). Pretoria: Government Printer.

SOUTH AFRICA. 2005. National Treasury. Treasury regulations. Available at: http://www.treasury.gov.za/ legislation/pfma/regulations/default.aspx [accessed 2011-01-08].

SOUTH AFRICA. 2009. National Treasury SCOA Technical Committee: Classification Circular 7 of 2008/09. Adjustments to the Standard Chart of Accounts (SCOA). Unpublished.

SOUTH AFRICA. 2010a. Marine Living Resources Fund. Department of Environmental Affairs and Tourism annual report - 2009/2010. Available at: http://www.info.gov.za/view/DownloadFile Action?id=132782 [accessed November 2011].

SOUTH AFRICA. 2010b. Limpopo Tourism and Parks Board. Annual report - 2009/2010. Annual report for the financial year ended 31 March 2010 of the Limpopo Tourism and Parks Board. Unpublished.

SOUTH AFRICA. 2011a. Mpumalanga Tourism and Parks Board. Annual report - 2010/2011. Available at: http://www.mpumalanga.gov.za/dedet [accessed November 2011].

SOUTH AFRICA. 2011b. North West Parks and Tourism Board. Annual report - 2010/2011. Available at: http://www.tourismnorthwest.co.za/ [accessed November 2011].

SOUTH AFRICA. 2011c. National Treasury. Public institutions listed in PFMA Schedule 1, 2, 3A, 3B, 3C and $3 \mathrm{D}$ as at 30 September 2011. South Africa. Available at: http://www.treasury.gov.za/legislation/pfma/ public\%20entities/2011-09-30\%20Public\%20institutions\%20Sch\%201-3D.pdf [accessed July 2012].

SOUTH AFRICAN NATIONAL PARKS (SANParks). 2011. Annual report. Available at: http://www.sanparks.org/assets/docs/general/annual-report-2011.pdf [accessed November 2011].

VAN SCHAIK, F. \& SANDERSON, I. 2008. IPSAS: Improving accountability across the world. Accountancy SA, October:26.

VAN SCHWEITZER, H. 2009. Internal audit - the conscience of the organisation. IA Adviser, February/ March:19. 